Athe Agriculture

Research Direction générale

Branch de la recherche

Contribution 1983-15E

\title{
Pest management approach in Quebec apple orchards
}

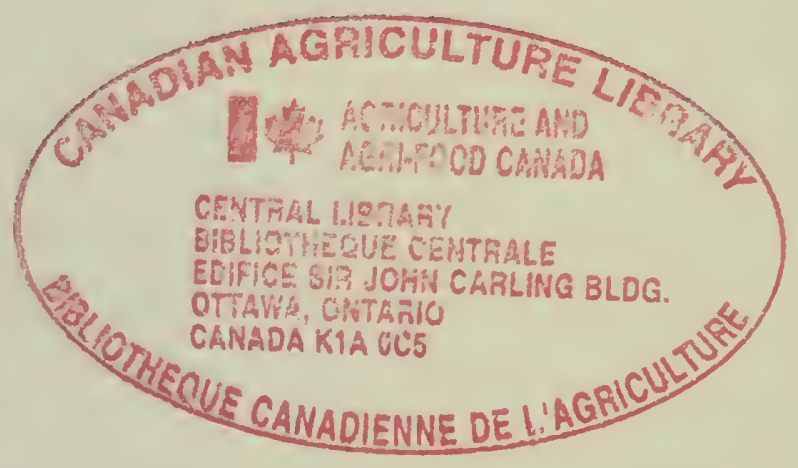

630.72

C759

C $83-15 E$

$\mathrm{OOAg}$

c. 3 


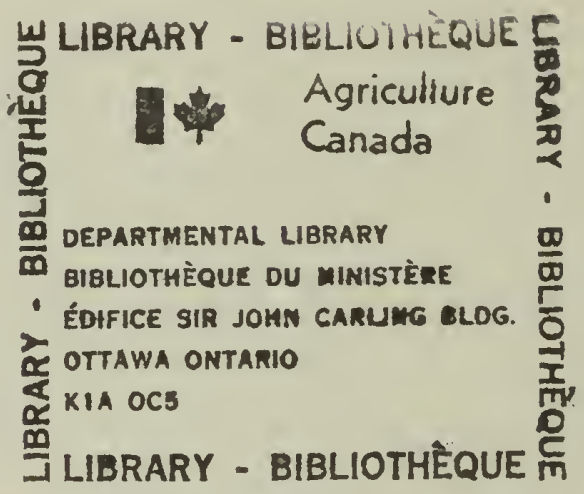




\section{Pest management approach in Quebec apple orchards}

RODOLPHE OMER PARADIS

Research Station

Saint-Jean-sur-Richelieu, Quebec

Technical Bulletin No. 16 revised

Research Branch

Agriculture Canada

1983 
Copies of this publication are available from Research Station

Research Branch

Agriculture Canada

P.O. Box 457

Saint-Jean-sur-Richelieu, Quebec J3B 6 Z8

Produced by Research Program Service

CMinister of Supply and Services Canada 1983

Également disponible en français sous le titre Lutte rationnelle contre les ravageurs des pommes au Québec 
Les insectes et les acariens ravageurs présents dans les pommeraies du sud-ouest du Québec sont passés en revue en fonction de leur comportement relié au développement phénologique du cultivar McIntosh ainsi qu'à des constantes thermiques. Il est fait mention également des principaux ennemis naturels de ces ravageurs.

La lutte chimique préconisée comporte cinq traitements appliqués à des stades-repères et à des dates prédéterminés; ces traitements sont dirigés contre les ravageurs prépondérants qui sont le Tétranyque rouge du pommier, Panonychus ulmi (Koch), la Mouche de la pomme, Rhagoletis pomonella (Walsh), les Punaises Lygus lineolaris (P. de B.), Lygocoris communis (Knight) et Lygidea mendax Reut., la Noctuelle du fruit vert, Orthosia hibisci (Guenée), et le Charançon de la prune, Conotrachelus nenuphar (Hbst.). Des essais de piégeage sont en cours et visent essentiellement à réduire le nombre de traitements insecticides.

Note Contribution no J. 847 de la Station de Recherches, Direction générale de la Recherche, Agriculture Canada, Saint-Jean-surRichelieu, Québec.

Communication présentée le 20 août 1980, au Colloque International sur l'Horticulture patroné par les Floralies de Montréal, Québec 

Abstract

The appearance and behaviour of phytophagous insects and mites occurring in apple orchards in southwestern Québec are presented along with the phenological development of the cultivar McIntosh coupled with degree-day summations. Natural enemies of these pests are also mentioned.

Chemical control measures require five pesticide treatments applied at different apple bud development stages and pre-determined dates. These treatments are directed against the major pests, $v i z$. the European red mite, Panonychus uImi (Koch), the apple maggot, Rhagoletis pomonelza (Walsh), the bugs Lygus lineolaris (P. de B.), Lygocoris communis (Knight) and Lygidea mendax Reut., the green fruitworm, Or thosia hibisci (Guenée), and the plum curculio, Conotrachelus nenuphar (Hbst.). Monitoring techniques are being evaluated with the aim of reducing pesticide treatments in apple orchards.

Note Contribution No. J. 847, Research Station, Research Branch, Agriculture Canada, Saint-Jean-sur-Richelieu, Québec.

Paper presented at a colloquium on horticulture held at the International Floralies, Montreal, Quebec, August 20, 1980 
First of all, I want to emphasize that this paper has been preparad with the assistance of my colleagues in the field of orchard protection in Québec, Mr. Marcel Mailloux of the Québec Department of Agriculture, Fisheries and Food, and Messrs. Irénée Rivard and Noubar Bostanian of Agriculture Canada. I have also made use of certain information provided by Mr. Guy Boivin, a student at McGill University, who is studying the complex of phytophagous plant bugs in apple orchards, and by Mr. Denis Bouchard, of the Université du Québec à Montréal, whose research deals with apple aphids.

The first part of this paper deals with the entomofauna of the apple orchards of southwestern Québec as it appears over the course of a season, first in relation with the phenological development of the cultivar McIntosh, which clearly predominates in our orchards, and then in relation to the calendar months for the rest of the season. For each of these stages, we give degree-days, calculated above $50 \mathrm{C}$ by the simple method of (maximum + minimum $/ 2)-5^{\circ} \mathrm{C}$. These thermal constants have been collected over the past ten years.

The entomofauna includes both pests and some of their principal natural enemies. Given the very large number of pests which attack apple trees, we have divided them into three categories: major pests, responsible for economic losses in most orchards unless treated; secondary pests, which cause serious local and episodic damage, and occasional pests, which in most cases cause negligible damage.

In the second part of the paper, we deal with the program of monitoring and control developed in recent years and further attempst to expand an improve upon it. 


\section{SPRING DORMANCY}

Period concerned: March 1 - April 28

Degree-days* as of April 1: 9 as of April 15: 20

Major pests:

Green fruitworm

Tarnished plant bug

Occasional pests:

Pale apple leafroller

Natural enemy:

Alzothrombium Zerouxii

* Above $5^{\circ} \mathrm{C}$, average of past 10 years

When the apple trees are still in their period of spring dormancy (PI. I, fig. 1), certain insects are already emerging from hibernation and beginning their activity. This is true of the green fruitworm, Orthosia hibisci (Guenée), and of the tarnished plant bug, Lygus lineolaris (P. de B.), two insects currently classified as major pests in Québec's apple orchards, that is, capable of causing economic losses in a very large number of orchards if untreated.

Green fruitworm

In 1980, the first catch of green fruitworm moths, by means of pheromone traps, occurred on April 10, approximately two weeks before the green-tip stage of the buds. The moths of this species are a greyish beige in colour, with densely hairy head and thorax and a wingspan of approximately $40 \mathrm{~mm}$ (P1. II, fig. 12). They fly about in orchards normally until midMay.

Tarnished plant bug

The first adults of the tarnished plant bug were captured on April 15, 
in 1980. They are small, oval-shaped, dull brown insects, measuring $6 \mathrm{~mm}$ in length, which fly away rapidly when disturbed (Pl. II, fig. 3).

Pale apple Zeafrolzer

The ale apple leafroller, Pseudexentera mali Free., is the only apple leaf roller which, according to our observations, attacks only apple trees, since other leaf rollers eventually infest various forest species. It owes its name to the whitish colour of the larvae, which are found well hidden in the leading shoots of the branches. We have occasionally observed P. mali adults flying about the orchards on April 8 and 9, when the maximum daily temperature was $12^{\circ} \mathrm{C}$ and the snow on the ground had not completely disappeared.

AZZothrombium Zerouxii Moss (P1. IV, fig. 1)

Among the rare entomophagous species present in orchards at this time of the year, we should mention the mite $A$. Lerouxii, which is $3,3 \mathrm{~mm}$ long and a velvety red, and is often plentiful immediately following the melting of the snow. It can be found hidden in dead leaves on the groung and it voraciously attacks the eggs and other forms of various species of mites and insects.

GREEN TIP

The budding of the apple trees, known in English as 'green tip' and frequently translated into French as 'bouton vert' or 'pointe verte', is an extremely important stage (P1. I, fig. 2). Besides being the first visible sign of renewed growth, it is at this period that apple scab, Venturia inaequalis (Cke.) Wint., may infect apple trees and that many pests make their presence known. In southwestern Québec, the earliest date for the green tip stage in McIntosh trees has been noted on April 16 and the latest on May 13; the average date however is April 29. 


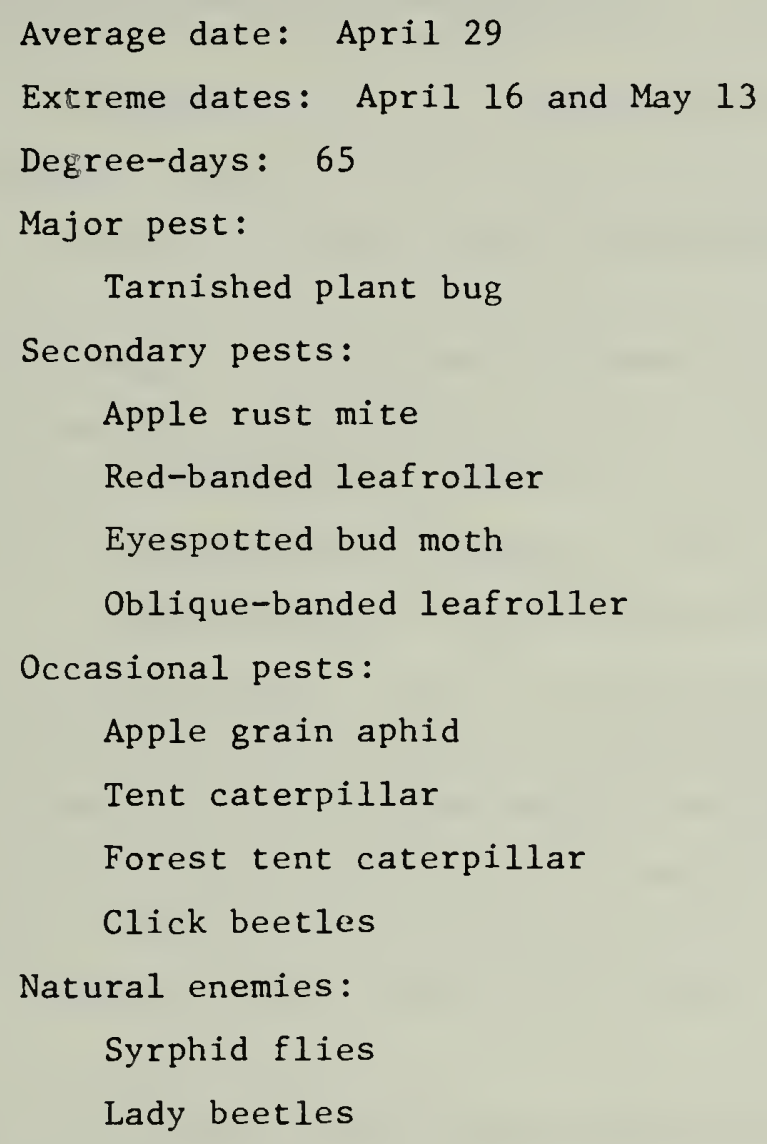

Here again we find the tarnished plant bug, which feeds by puncturing the flower and leaf buds, thus causing them to exsude fluid and dry out. We have observed that, in some plantings, the proportion of buds thus destroyed can easily be in the range of $30 \%$.

Apile must mite (PI. II, fig. 2)

The apple rust mite, Aculus schlechtendali (Na1.), is an increasingly frequent and serious pest in Québec's apple orchards. Measuring approximately $0,07 \mathrm{~mm}$ in length, it is invisible to the naked eye, but as the season progresses and leaves turn brown, its presence becomes 
readily apparent. The hibernating females, described as deutogynes, leave the budscales in which they have passed the winter to attack foliar tissue during the green tip stage.

\section{Red-banded leaf rolzer}

After spending the winter in pupal form in plant litter on the ground, the first moths of the red-banded leaf roller, Argyrotaenia velutinana (W1k.), are caught by means of synthetic pheromones at the green tip stage. These are small moths with a wingspan of approximately $13 \mathrm{~mm}$, the forewings having an oblique shaded band of red and brown.

Adults of the hibernating generation continue to be caught until mid-June. Sometimes large numbers are captured, but it should be emphasized that the species is polyphagous and that the caterpillars may be present in greater quantities, for example, on plants of the genus Apocynum sp. growing in certain orchards than on the apple trees themselves.

Oblique-banded leaf rolzer and Eyespotted bud moth (P1. III, figs. 4 and 8)

The oblique-banded leaf roller, Archips rosaceana (Harr.), and the apple budmoth, Spizonota ocelzana (D. \& S.), spend the winter as young caterpillars on the trees. During the green tip stage these caterpillars begin their activities again, hiding inside the buds to feed.

A. rosaceana caterpillars are yellowish green with darker heads, while S. ocelzana are chocolate brown.

Aprie grain aphid

Of the four species of aphids found on apple trees, the apple grain aphid, Rhopalosiphum fitchii (Sand.), is the first to make its appearance. Populations are rarely large enough to require treatment. At the calyx stage, the winged forms appear, and then migrate to various grains and grasses. 
Easterm tent caterpizlar and Forest tent caterpizlar

At the end of April, at the green tip stage, the caterpillars of Malacosoma cmericanum (F.) and MaZacosoma disstria Hbn. appear. The caterpillars of both species live in colonies, but only those of $M$. americanum spin webs in the forks of the trees. In carefully maintained orchards, they are readily eliminated by regular applications of insecticide. Their larval stage is completeted by mid-June.

click beetles

These are the adults of the wireworms. Some of these adults, particularly those of the genus Ctenicera spp., eat the buds of the apple trees and attack the blossoms as well, after which they leave the apple trees. They are occasional pests.

Syrphid flies

At the green tip stage, it is possible to find syrphid eggs laid on buds infested by the apple grain aphid (P1. IV, figs. 2 and 3). The larvae of these Diptera are among the major predators of aphids throughout the entire season. According to studies carried out by Mr. Denis Bouchard, there are at least seven species in our orchards.

Lady beetzes (P1. IV, fig. 3a)

Early in the season, we find large numbers of lady beetles moving about in search of food. Eight species which attack aphids have been identified.

\section{HALF-INCH GREEN}

Advanced budding is characterized by leaves at least $12 \mathrm{~mm}$ in length. American pomologists use the expression 'half-inch green' to describe this stage. In French, it is often known as 'bouton vert avancé' or 
'oreilles de souris' (P1. I, fig. 3). Apple trees reach this stage of development at an average date of May 2, while the extreme dates are April 20 and May 20. Degree-days accumulated by this point total approximately 85 units. At this phenological stage, the first dandelions, Taraxacum officinale, and trilliums, Trizlizm grandiflomm and T. erectum, appear in the orchards.

At the half-inch green stage, we find the pests already listed, plus the two-spotted spider mite, Tetranychus urticae Koch, the rosy apple aphid, Dysaphis plantaginea (Pass.), the tentiform leafminer, Lithocolletis blancardelza (F.) and the gypsy moth, Lymantria dispar (L.).

Average date: May 2

Extreme dates: April 20 and May 20

Degree-days: 85

Secondary pests:

Two-spotted spider mite

Rosy apple aphid

Occasional pests:

Tentiform leafminer

Gypsy moth

Two-spotted spider mite

The two-spotted spider mite is a cosmopolitan and polyphagous mite found in greenhouses as well as in the field; it is classed as a secondary pest of Québec apple orchards. The hibernating females, which are an orangeish yellow in colour, normally appear at the half-inch green stage. At this point they are found on herbaceous plant growing in the orchards, particularly white campion, Lychnis alba. It is not until late June or early July, when the cover crops have dried up or been mowed back, that the two-spotted spider mite attacks the apple trees. The species 
completes five or six generations in southwestern Québec.

Rosy apple aphid (P1. III, figs. 2 and 3)

Heavy infestations of the rosy apple aphid occur only very sporadically. In addition, in mid-June, there is a heavy migration of the winged forms to secondary hosts.

\section{Appleminers}

The complex of appleminers in Québec includes the following species: Lithocolletis malimalifoliella (Braun), L. scuderella (F. \& B.), L. crataegella Clem., and L. blancardella (F.). L. blancardella is currently predominant; it completes three generations annually and spends the winter as a pupa in the dead leaves. The adults make their appearance at the half-inch green stage. During the spring of 1980, we monitored L. blancardella for the first time, by means of a synthetic sexual pheromone.

Gypsy moth

There has been a renewed outbreak of this pest on deciduous species in several regions of Québec. In some orchards, in recent seasons, we have observed the presence of the blackish, long-haired caterpillars of the gypsy moth, which often feed on the upper surface of the leaves. Their development is completed by the second half of June. However, to date, heavy infestations of orchards have occurred only occasionally.

\section{TIGHT CLUSTER}

At shis stage, flower buds begin to appear, but they are all clustered tightly together; hence the English expression 'tight cluster' (P1. I, fig. 4). The average date for the appearance of the tight cluster is May 9, while the extreme dates range from April 29 to May 23. 
Average date: May 9

Extreme dates: April 29 and May 23

Degree-days : 125

Major pest:

Green fruitworm

Secondary pest:

Apple aphid

Green fruitworm (P1. II, figs. 11 and 13)

At this point in the season, the caterpillars of the green fruitworm appear; they continue to develop until approximately two weeks after petal-fall. These caterpillars attack the buds and new shoots and later the newly formed apples, in which they leave deep holes and cavities. They are pale green, lightly lined in white; at full size, they measure 30 to $40 \mathrm{~mm}$ in length.

Apple aphid (P1. III, fig. 1)

At the tight cluster stage, we observe colonies of the apple aphid, Aphis pomi De $G$, on the leading shoots. This species spends the entire season on the apple tree. The winged forms, which appear somewhat later, enable it to spread throughout the orchards. When populations become extremely dense during the course of the season, they cause sooty fungus on the foliage and fruit.

PINK BUD

At this stage, the flower buds become separated from one another and each bud shows a distinctly pink section of petals (P1. I, fig. 5). The pink bud stage normally occurs in mid-May; however, the earliest date has been May 6, and the latest, May 29. At this stage, there has been a total of 165 degree-days. 


\section{Average date: May 15 \\ Extreme dates: May 6 and 29 \\ Degree-days: 165 \\ Major pests: \\ European red mite \\ Plum curculio \\ Secondary pest: \\ Fruit-tree leafroller}

European red mite (P1. II, fig. 1)

The eggs of the European red mite, Panonychus uImi (Koch), which have spent the winter on the bark of the branches and trunks, hatch in large numbers each year at the pink bud stage. It should be noted that $P$. uImi is one of the worst apple pests in Québec. It multiplies very readily on the trees, and can complete six or seven generations in a season. In order to feed, it sucks out the cullular material from the leaves, leaving them discoloured; it thus reduces the vigour of the tree and the development of the fruit buds; it can even cause premature dropping of the fruit. The cost of treatments applied against the European red mite and other mites represents approximately $30 \%$ of the total cost of treatments against all pests.

Plum curculio (P1. II, fig. 8)

The first hibernating adults of the plum curculio, Conotrachelus nenuphar (Hbst.), also appear at the pink bud stage. Despite its name, this insect if found predominantly in Québec's apple orchards and, because it has very few natural enemies, insecticides must be used to protect the apples from its attacks. 
Friit-tree leafrolzer (P1. III, fig. 9)

The fruit-tree leafroller, Archips argyrospilus (Wlk.), is classified as a secondary pest. The eggs, laid in patches on the bark of the trees, constitute the hibernation stage and hatch primarily during the pink bud stage. The caterpillars, which are green with black heads, eat the first elements of the foliar tissues and the various floral organs; then, using strands of silk, they roll the leaves into sheaths in which they hide, eating the foliar parenchyma here and there and also attacking newly formed apples in the vicinity of their shelter. The damage caused to the fruit can be easily confused with that caused at the same period by the caterpillars of the green fruitworm and those of the oblique-banded leaf roller (P1. II, fig. 13, P1. III, fig. 10).

FULL PINK

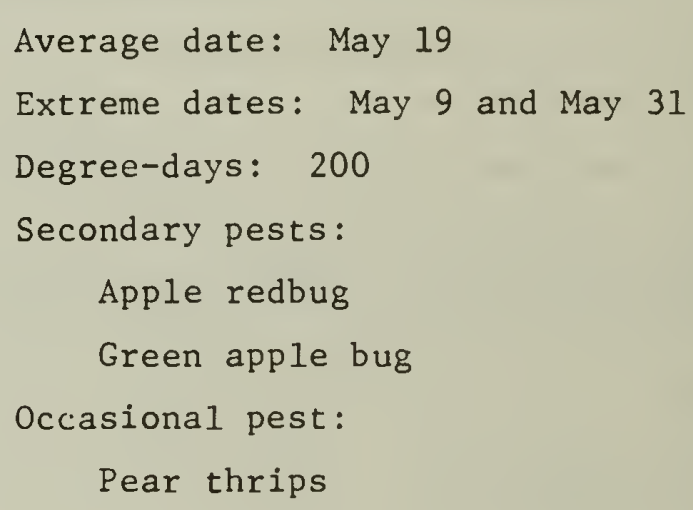

This stage is fairly closely related to the preceding one. It is distinguished by the fact that the petals are much more highly developed but are still clustered together, forming a pink and white balloon (P1. I, fig. 6). The average date of appearance of the full pink bud stage is May 19, with an accumulated total of 200 degree-days. The earliest observed date has been May 16 and the latest, May 31. 
The full pink bud stage is still an important one in scab control programs. In terms of pests, the species already mentioned continue to develop, along with the green apple bug, Lygocoris communis (Knight), the apple redbug, Lygidea mendax Reut. and the pear thrips, Taenis thrips inconsequens (Uzel).

Apple redbug and Green apple bug

These two species of mirid bugs spend the winter as eggs hidden in the twigs and leading shoots of the branches. The larvae emerge at the full pink bud stage; the larvae of the apple redbug are bright red and those of the green apple bug are pale green. Current studies appear to indicate that these pests do more damage to apples than was previously believed.

Pear thrips

Despite its name, this insect also attacks apple, plum, cherry and peach trees, as well as certain forest species. The adults are black and measure approximately $1,5 \mathrm{~mm}$ in length. They burrow into the developing apple blossom and feed by puncturing the various organs, thus causing tissues to turn brown and die. In addition, the females cause other lesions by implanting their eggs in the petioles of the flowers and fruit and in the central veins of the leaves. The larvae, which are yellowish white in colour, drain the cellular material in the same way as the adults, complete their development in June and then fall to the ground for the pupal stage. The species is univoltine.

\section{FULL BLOOM}

At this stage, all the blossoms are open (P1. I, fig. 7). The average date of full bloom is May 23, with an accumulated total of 240 degreedays. The earliest observed date of flowering has been May 13 and the latest, June 5 . 


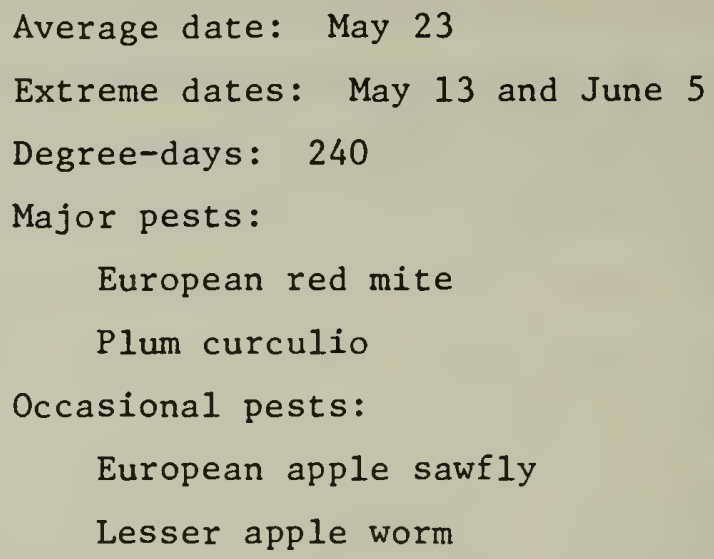

This is the period of pollinization; a recent study on this topic assessing the importance of insects with respect to certain other pollinizing agents has been conducted in an orchard in southwestern Québec by Miss Suzanne Pion and is soon to be published.

European red mite

The first females and the first eggs of the European red mite appear during the flowering stage. The species has thus completed its first generation.

Plum curculio

The adults of this pest actually invade the apple trees during the full bloom period. At this time, they feed on the petals of the flowers.

European apple sawfly

First noted in Canada in 1940, the European apple sawfly, Hoplocampa testudinea (Klug), was found until recently only on Vancouver Island, in Bristish Columbia. However, in June 1979, this pest was observed for the first time in Québec; in the spring of 1980, it was again found in a number 
of orchards in the southwestern part of the Province. This insect spends the winter in the larval state on the ground and the adults appear on the apple trees at the beginning of the flowering period. They measure approximately $6 \mathrm{~mm}$ in length; their wings are transparent with prominent dark ribs. The abdomen and thorax are black on the dorsal portion and yellowish brown on the ventral portion (P1. III, fig. 11).

The female lays her eggs in the flower receptable at the base of the sepals. The larva hatches during the fruit-setting stage and excavates a superficial gallery around part of the fruit. Later, the larva burrows to the centre of the fruit, leaving a large hole surrounded by excrement. The species is univoltine.

Lesser apple worm

Monitoring of the lesser apple worm, Grapholitha pmunivora (Walsh), by means of a synthetic pheromone, indicates the presence of the first adults in the orchards towards the end of the flowering period.

These adults are minuscule moths, tarnished black in colour. Under the binocular lens, however, their forewings are rather dark brown with light orange brown and blue markings; they have a wingspan of approximately $10 \mathrm{~mm}$. The caterpillars, which have brown heads and pinkish white bodies, measure $8 \mathrm{~mm}$ in length at full size. They feed on the apples in the same way as the codling moth, Laspeyresia pomonella (L.). The damage which they cause is very rarely of economic importance.

\section{PETAL FALL}

The calyx stage is reached when $90 \%$ of the petals of the flowers have fallen, which usually occurs during the last days of May (P1. I, fig. 8). The extreme dates for the petal fall are May 20 and June 7; the average date is May 29. Degree-days to this point total 300 units. 
Average date: May 29

Extreme dates: May 20 and June 7

Degree-days : 300

Secondary pests:

Codling moth

Oystershell scale

European fruit scale

Red-banded leafroller

codling moth (P1. III, figs. 6 and 7 )

The first adults of the codling moth are usually captured, by means of a synthetic pheromone, during the petal fall. At this point, degree-days above $11^{\circ} \mathrm{C}$, calculated by the Baskerville and Emin method ${ }^{1}$, total 110 units.

This insect is known around the world and is classified in several countries as a major apple pest. In Québec, however, for the past two decades, it has been considered a secondary pest, having been replaced by the apple maggot, Rragoletis pomonella (Walsh). Regular applications of insecticides to control this insect act against the codling moth as well and keep it below the damage level. In fact, in neglected orchards, codling moth populations are quite large and they do considerable damage.

Oystershezl scale

The oystershell scale, Lepidosaphes $u I m i$ (L.), spends the winter in the

1 Baskerville, G.L. and P. Emin. 1969. Rapid estimation of heat accumulation from maximum and minimum temperatures. Ecology 50: 514-517.

Trottier, R. 1980. Early warning system for apple pest management in Canada. EPPO BulZ 10: 253-257. 
egg stage hidden under small comma-shaped scales attached to the bark of the branches. These eggs hatch during the petal fall; the new larvae are mobile for only a short period of time, after which they attach themselves somewhere on the twigs, branches or occasionally fruit to complete their life cycle and to cover themselves over progressively with scales. It is during the insect's mobile stage that treatment should occur, if required.

European fruit scale

With its tiny, round, slightly convex scale, the European fruit scale, Quadraspidiotus ostreaeformis (Curt.), can be readily distinguished from the oystershell scale. The species is believed to spend the winter in the larval stage; males and females are present in the orchards at the calyx stage and this is the best time for control. However, its evolutionary cycle has never been studied in Québec.

Red-banded leaf roller

The caterpillars of this leafroller, which are pale green with straw yellow heads, hatch during the calyx stage. If the populations are large enough, this is the stage at which the first treatment should be applied.

\section{FRUIT SET}

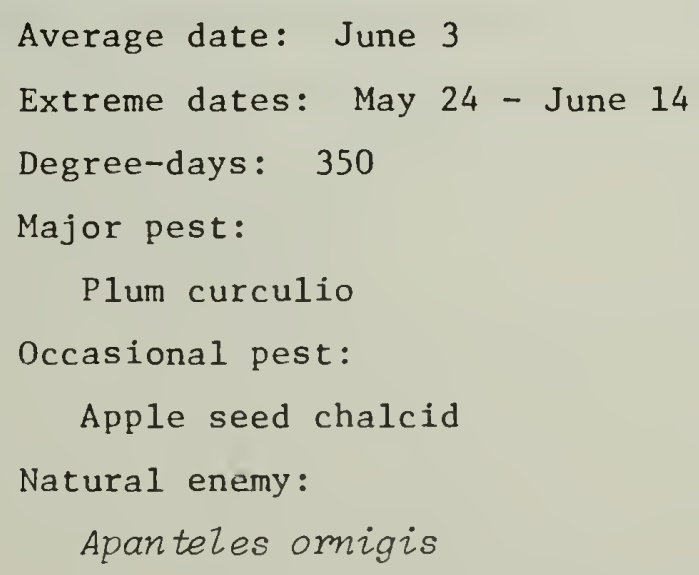


Setting occurs approximately five days after the calyx stage; at this point, the apples are only about $6 \mathrm{~mm}$ in diameter (P1. I, fig. 9). The average date for setting is June 3, while the extreme dates are May 24 and June 14 .

Plum curculio

As soon as the apples have set, the plum curculio lays its eggs on them, leaving a crescent-shaped scar on the fruit (P1. II, fig. 9). This pest lays $80 \%$ of its eggs in June.

Apple seed chalcid, Torymus varians (Wlk.)

This small, bright green Hymenopteron, 3 to $4 \mathrm{~mm}$ long, appears at the setting stage and remains active for the next three weeks. The females lay their eggs directly in the seeds of the apples; the larva develops within the seed and spends the winter there. This chalcid in an occasional pest and the damage which it causes is often confused with that caused by the apple maggot.

Apanteles omigis (Weed) (PI. IV, fig. 10)

This braconid plays a role of primary importance in the control of the leafminer populations. In recent seasons, it has been noted that in orchards infested by the apple leaf miner, the rate of parasitism by A. omigis was occasionally as high as $85 \%$. The adults of this braconid appear during the setting stage. 
JUNE

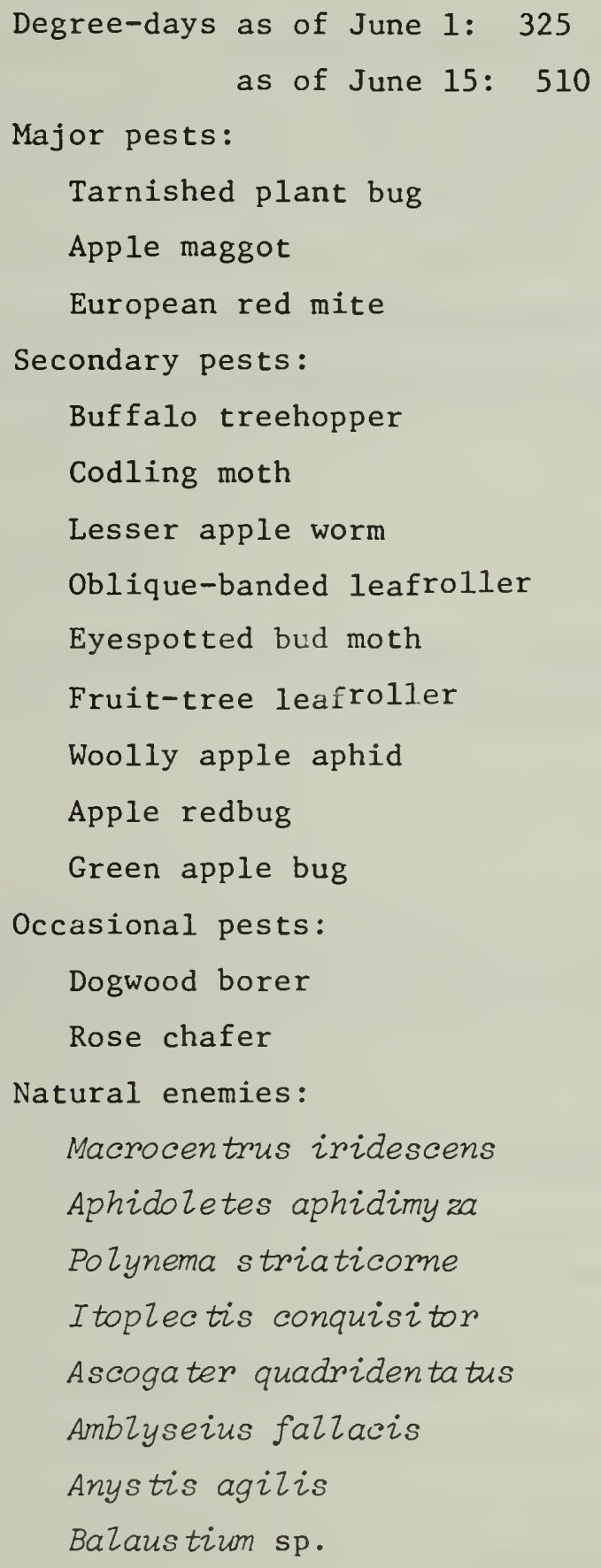


tree to confine itself to the cover crops.

Apple maggot (P1. II, figs. 6 and 7)

One of the most important orchard insects, the apple maggot, Rhagoletis pomonella (Walsh), appears at an average date of June 25 (extremes: June 20 and July 5). At this time, the accumulated degree-days total 450 units above $9^{\circ} \mathrm{C}$, calculated according to the Baskerville-Emin formula cited above. For a number of years, the apple maggot has been subject to monitoring in Québec.

European red mite

Most of the individuals appearing during the month of June are members of the 2 nd and 3rd generations.

Buffalo treehopper

The hibernating eggs of the buffalo treehopper hatch during the first half of June. The nymphs and adults feed on herbaceous plant, preferably leguminous plants.

Codling moth and Lesser apple worm

Large numbers of these two species are still being captured by means of synthetic pheromones during the entire month of June. The eggs of the codling moth hatch about mid-June, when accumulated degree-days total 210 units above $11^{\circ} \mathrm{C}$, as calculated by the Baskerville-Emin formula.

\section{Obzique-banded Zeafrolzer}

Catches of oblique-banded leafroller moths begin between June 10 and 15 , and reach their peak at the end of June and the beginning of July. 
Eyespotted bud moth and Fruit-tree Zeafrolzer

As with the previous species, the adults of these two pests are particularly numerous at the end of June and the beginning of July.

Woolly apple aphid

In mid-June, the woolly apple aphid, Eriosoma Zanigemon (Hausm.), can already be found, particularly on incompletely healed wounds caused by the pruning of the apple trees.

Apple redbug and Green apple bug

The adults of these two univoltine species appear in June (P1. II, figs. 4 and 5).

Dogwood borer

The adults of the dogwood borer, Thamosphecia scitula (Harr.), with its black body, yellow markings and transparent wings, are active from the end of June to mid-July. The caterpillar of this species is whitish and feeds on sap, remaining in tunnels under the bark of apple trees which are already weak and lacking in vigour. Reddish wormholes on the bark reveal its presence. Since 1979, tests aimed at monitoring this species have been carried out.

Rose chafer

Towards mid-June, the adults of the rose chafer, Macrodactylus subspinosus (F.), occasionally attack certain orchards planted near very sandy areas. These beetles, approximately $9 \mathrm{~mm}$ long, are yellowish brown in colour, have long legs, and chew holes of varying depths in the fruit. 
Macrocentrus iridescens French (P1. IV, fig. 6)

In an experimental orchard which received no insecticide treatment, this polyembryonic bracomid has, in the last two seasons, practically eliminated the hibernating caterpillars and first-generation caterpillars of the oblique-banded leafroller. This species merits special attention.

Aphidoletes aphidimyza (Rondani) (P1. IV, fig. 7)

This cecidomyid, which is a major predator of the apple aphid, the rosy apple aphid and the woolly apple aphid, appears at the beginning of June.

Polynema striaticome Gir.

This is a chalcid, the adults of which appear during the first half of June and which is an important parasite of buffalo treehopper eggs.

I toplectis conquisitor (Say) (P1. IV, fig. 8)

This endoparasite is very common and attacks a number of insects, particularly the leafrollers and the apple bud moth.

Ascogaster quadridentatus (Wes.) (P1. IV, fig. 11)

This braconid, approximately $4 \mathrm{~mm}$ long, attacks the eggs of the codling moth and develops within the larva. The adult appears in mid-June as the first codling moth larvae are hatching. In commercial orchards, the rage of parasitism is approximately $6 \%$, but may go as high as $25 \%$.

Amblyseius fallacis (Gar.) (P1. IV, fig. 12), Anystis agilis Banks and Balaustium sp.

The predators of the European red mite are extremely numerous, but disappear from commercial orchards as a result of insecticide treatments. 
A. fallacis, A. agilis and Balaustirm sp. are the only species found in small numbers in commercial orchards after mid-June.

In 1979, there was a first attempt to introduce specimens of Amblyseius fallacis which were resistant to certain organophosphate insecticides. The results obtained have been extremely encouraging.

\section{JULY}

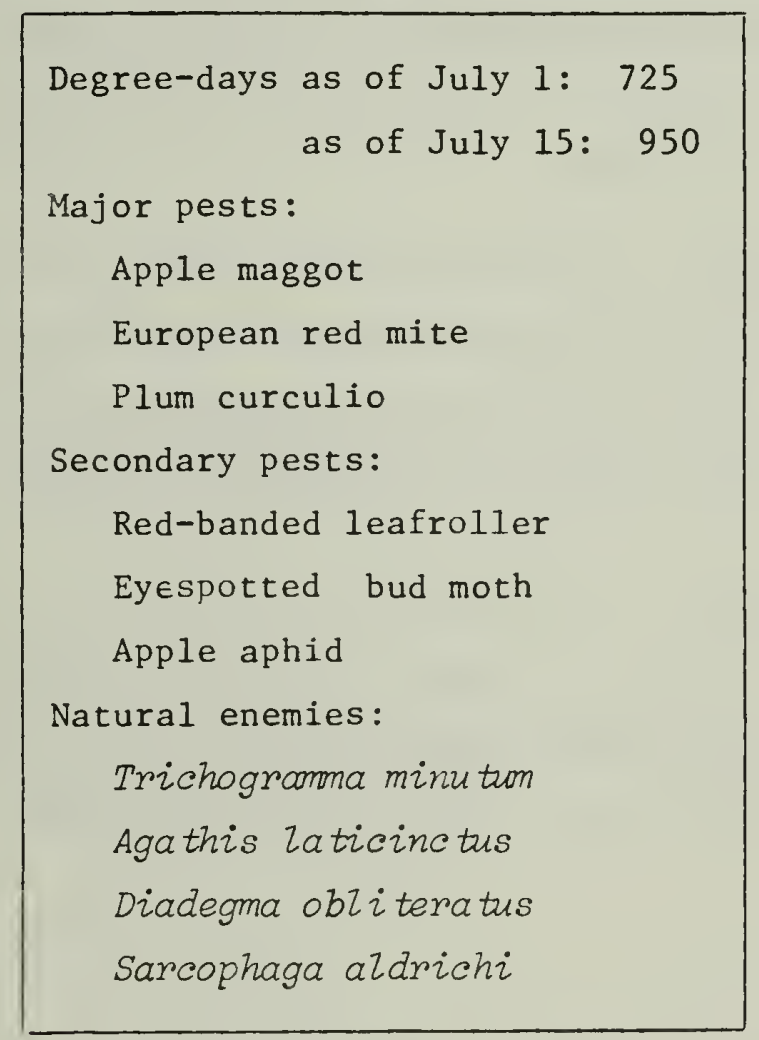

Apple maggot

The period of maximum activity for this insect occurs from mid-July to mid-August. 
European red mi te

In July, most of the individuals are members of the 3 rd and 4 th generations; populations normally reach their highest density by the end of July and the beginning of August.

Plum curculio

Towards mid-July, the larvae of this curculio leave the apples and burrow into the ground where they will spend the pupal and adult stages; the adults appear primarily during the 3 rd week of August. The presence of new adults is revealed primarily by an increase in the number of feeding punctures (P1. II, fig. 10).

Red-banded Zeafrozzer

The beginning of July marks the first catches of adults of this leaf roller, which will give birth to the second generation.

\section{Eyespotted bud moth}

Large numbers of caterpillars of the new generation, which will become the hibernating caterpillars, appear around July 20.

Apple aphid

By late July, there is usually a sharp decline in the populations of apple aphids, which may be due to climate conditions and the leathery condition of the foliage.

Trichogrooma minutum Riley

In Québec's apple orchards, this cosmopolitan parasite has of ten been observed in July emerging from the eggs of the red-banded leaf roller and 
the apple budmoth, among others.

Agathis Zaticinetus (Cress.) (P1. IV, fig. 4)

This braconid is a major parasite of the eyespotted budmoth, and may reduce larval populations by as much as $50 \%$. The adults appear about mid-July.

Diadegma obliteratus (Cress.) (P1. IV, fig. 5)

This parasite attacks leaf rollers, olethreutids and leaf miners.

Sarcophaga aldrichi Park. (P1. IV, fig. 9)

This tachinid attacks the cocoons of the forest tent caterpillar in particular, and can decimate this species in neglected orchards.

AUGUST

Degree-days as of August 1: 1200

as of August 15: 1450

Major pest:

European red mite

Secondary pests:

Codling moth

Lesser apple worm

Buffalo treehopper

Red-banded leaf roller

Woolly apple aphid

Apple rust mite 
European red mite

This mite completes its 4 th and 5 th generations and, during the month of August, the first hibernating eggs can be found on the bark of the branches or in the eyes of the apples.

Codling moth and Lesser apple worm

At the beginning of August, the moths of these two pests, which will give birth to a partial second generation, appear.

Buffalo treehopper

Also at the beginning of August, the females of the buffalo treehopper leave the herbaceous plants and invade young apple trees. Besides laying their eggs deep in the inner bark of the trunks and twigs, they make two slits in the bark near each group of eggs. When there are many of these slits, they can interfere with the growth of the young trees.

\section{Red-banded Zeafrozzer}

Nearly all the caterpillars of the second generation of this leafroller have hatched by the beginning of the month of August.

Woolzy apple aphid

It is also at the beginning of August that we observe heavy infestations of the woolly apple aphid, which, in recent years, have become more widespread.

Apple rust mite

It is during the month of August that the first deutogynous females appear, those that will spend the winter beneath the scales of the buds 
or in the folds of the bark.

II - MONITORING AND CONTROL

Under current conditions, it is difficult to visualize comercial apple production without the use of a certain number of insecticide treatments. For this reason, we propose basic treatments which are suitable for most orchards and directed against the major pests, which at the present time are the European red mite, the apple maggot, the phytophagous plant bugs, the plum curculio and the green fruitworm. Where necessary, we also recommend additional or special treatments for local and seasonal problems.

The basic treatments include a preliminary application of insecticide at the pink bud stage, directed against the tarnished plant bug and the green fruitworm. This treatment may also have a repressive effect on secondary or occasional pests present at this time, such as the tent caterpillars, the oblique-banded leafroller, the fruit-tree leafroller, the leafminers, the bud moth and the aphids (Table 1 ).

A second treatment, recommended at the calyx stage, is directed against the plum curculio and against the plant bugs; it may also be effective against the scales, the red-banded leafroller, the European apple sawfly, the gypsy moth and, again, against the aphids.

A third treatment is carried out against the European red mite and is applied when an average of five mobile forms of this mite can be found on each leaf. In some cases, it can be combined with the previous or subsequent application. This treatment also eliminates the populations of the apple rust mite and the two-spotted spider mite.

A fourth and fifth basic treatment are performed towards July 10 and July 25 respectively against the apple maggot; these treatments may also be effective against the apple worms, the aphids, the leafrollers and the eyespotted bud moth. 
TABLE 1 Basic treatments directed against major pests in relation to secondary or occasional pests which may be present.

\begin{tabular}{|c|c|c|}
\hline $\begin{array}{l}\text { Time of } \\
\text { treatment }\end{array}$ & $\begin{array}{l}\text { Major } \\
\text { pests }\end{array}$ & $\begin{array}{l}\text { Secondary of } \\
\text { occasional pests }\end{array}$ \\
\hline Pink bud & $\begin{array}{l}\text { tarnished plant bug } \\
\text { green fruitworm }\end{array}$ & $\begin{array}{l}\text { tent caterpillars, oblique- } \\
\text { banded leaf rollers, fruit- } \\
\text { tree leaf roller, leaf } \\
\text { miners, bud moth, aphids }\end{array}$ \\
\hline Calyx & $\begin{array}{l}\text { plum curculio and } \\
\text { phytophagous plant } \\
\text { bugs }\end{array}$ & $\begin{array}{l}\text { scales, red-banded leaf } \\
\text { roller, aphids, sawfly, } \\
\text { gypsy moth }\end{array}$ \\
\hline $\begin{array}{l}\text { June or } \\
\text { July }\end{array}$ & european red mite & $\begin{array}{l}\text { apple rust mite, two-spotted } \\
\text { spider mite }\end{array}$ \\
\hline July 10 & apple maggot & $\begin{array}{l}\text { codling moth, aphids, } \\
\text { leaf rollers, bud moth }\end{array}$ \\
\hline July 25 & apple maggot & $\begin{array}{l}\text { codling moth, aphids, } \\
\text { leaf rollers, bud moth }\end{array}$ \\
\hline
\end{tabular}

With additional or special treatments, certain precautions must be taken, since, for example, the leaf miner populations to be eliminated may be heavily infested with parasites or the aphid colonies involved may include numerous predators. In these cases, applications of insecticides are not only useless, but harmful. This is when a knowledge of the principal parasites and predators normally present in orchards becomes very important to both the agricultural adviser and the fruit grower himself.

A monitoring program can also prove very useful in determining the presence of a given pest, the density of the population and the need for treatment. Two types of traps are currently being used with success in certain orchards in Québec:

- the synthetic sexual pheromone trap, and

- the bait trap, based primarily on colour attraction.

The pests currently subject to monitoring can be divided as follows: 
Red-banded leafroller

(1)

Codling moth (1)

Oblique-banded leafroller

Fruit-tree leafroller

(1)
Apple maggot (1)

Tarnished plant bug (4)

Apple sawfly (4)

Lesser apple worm (1)

Dogwood borer (2)

Leafminer

Green fruitworm (3)

The pheromone trap holds a capsule impregnated with a synthetic substance similar to that given off by the female of a given species. This capsule is placed in a flared, pre-glued cardboard trap; it can be effective over an area of approximately two hectares for a month.

The bait trap for the apple maggot is made of pre-glued yellow cardboard $(14 \times 23 \mathrm{~cm})$ with an ammoniac-based bait. It should be placed in the areas most subject to attacks by this maggot. The bait trap for the tarnished plant bug and the european apple sawfly is made of cardboard $(15 \times 20 \mathrm{~cm})$ covered with white zinc pigments which do not reflect ultraviolet radiation and with a glue known as Tangletrap ${ }^{(R)}$.

For the red-banded leafroller, the codling moth, the oblique-banded leaf roller and the apple maggot, mentioned in the table below, we are in a position to give the dates for trap installation, the monitoring periods and the critical number of catches at the end of the monitoring period:

(1) Zołcon Corporation, Palo Alto, California 94304.

(2) Conrel, Needham Heights, Massachusetts 02194.

(3) Prairie Regional Laboratory, NRC Canada, Saskatoon, Sask S7N 0W9.

(4) New England Insect Traps, Colrain, Massachusetts 01340. 


\begin{tabular}{|c|c|c|c|c|}
\hline Insect & $\begin{array}{l}\text { Date of trap } \\
\text { installation }\end{array}$ & $\begin{array}{l}\text { Trapping } \\
\text { period }\end{array}$ & $\begin{array}{l}\text { Critical } \\
\text { of total }\end{array}$ & $\begin{array}{l}\text { number }^{1} \\
\text { catches }\end{array}$ \\
\hline Red-banded leaf roller & April 15 & April 20 - May & 20 & 600 \\
\hline Codling moth & May 15 & May 20 - June ? & & 20 \\
\hline $\begin{array}{l}\text { Oblique-banded leaf- } \\
\text { roller }\end{array}$ & May 25 & June 1 - July & & 100 \\
\hline Fruit-tree leafroller & June 15 & June $20-J u l y$ & 20 & 20 \\
\hline $\begin{array}{l}\text { Red-banded leafroller } \\
\text { (2nd generation) }\end{array}$ & June 20 & June 25 - July & 25 & 200 \\
\hline Apple maggot & June 20 & June 25 - Sept & ember 1 & 1 \\
\hline $\begin{array}{l}\text { Oblique-banded leaf- } \\
\text { roller ( } 2 \text { nd generation) }\end{array}$ & August 1 & August 5 - Sep & tember 5 & 100 \\
\hline
\end{tabular}

1 Sum of catches in 2 traps per orchard, except for the apple maggot, with 4 traps per orchard. The critical numbers of catches may be modified following further information.

The critical thresholds which we suggest are provisional and, for proper use of these monitoring techniques, the inexperienced fruit grower should consult an agricultural adviser. For species not listed in the table, research is continuing in an effort to establish the relationship between catches and damage with all possible accuracy.

This brief survey of the area of apple orchard protection against pests is, of necessity, incomplete; it may help, however, to demonstrate the complexity of the problems and the efforts which have been made to develop a rational, rather than preventive and empirical, policy of control. 


\section{Acknowledgements}

Messrs. A. Clément, D. Pitre and L.G. Simard of Agriculture Canada and Mr. J. Touzin of the Québec Department of Agriculture, Fish and Food have made an important contribution as technicians to the basic work of this research. In addition, with the assistance of Mr. B. Drouin, a graphic artist with the Québec Department of Agriculture, Fisheries and Food, they have prepared the colour plates illustrating this report. 
PLATE I - Phenological stages in the development of McIntosh apple trees
1. Dormant
2. Green tip
3. Half-inch green
4. Tight cluster
5. Pink
6. Advanced pink
7. Full bloom
8. Petal fall
9. Fruit set

Pho tos:

L.G. Simard 

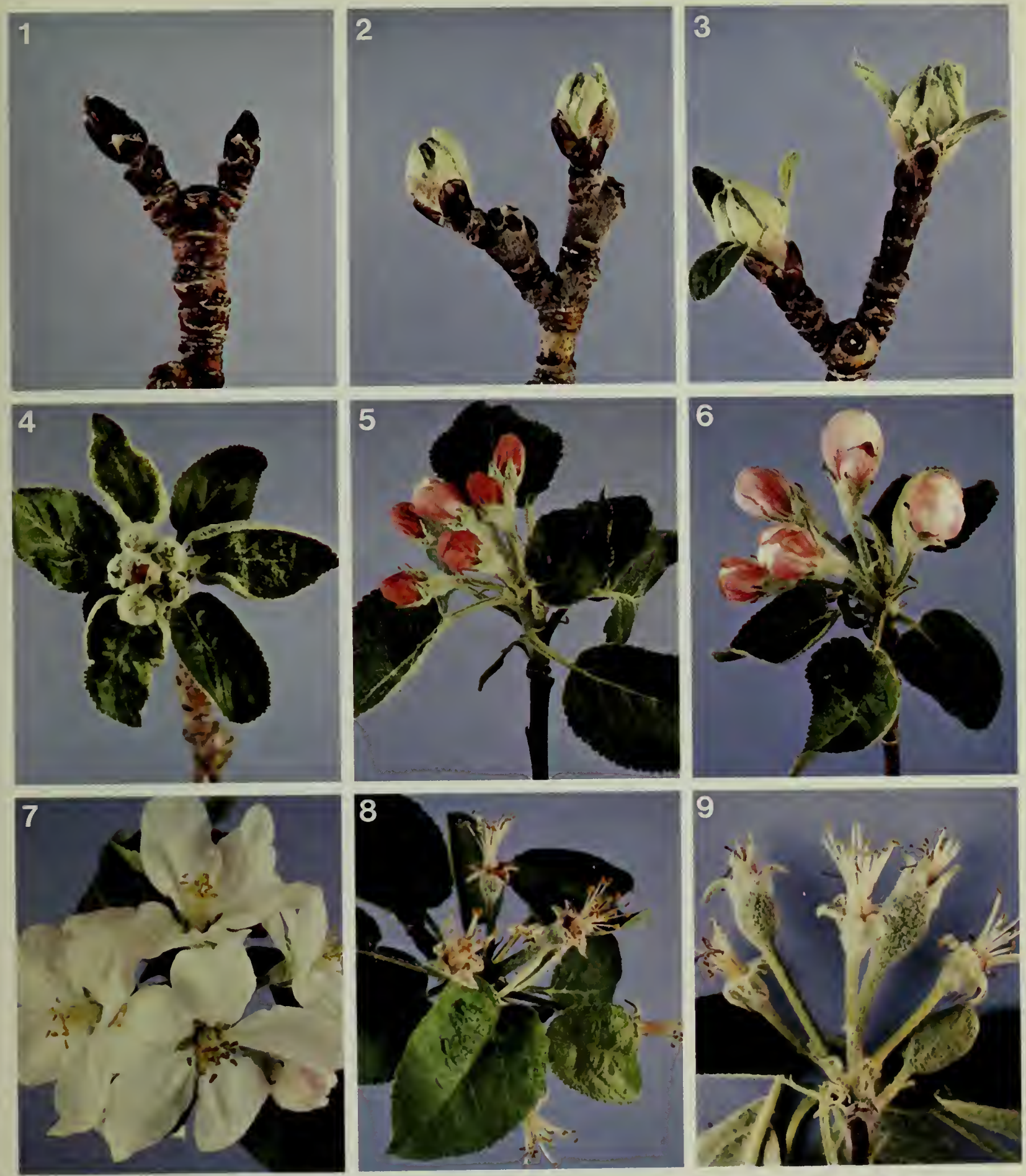


PLATE II - Major apple pests

1. Female European red mite, Panonychus ulmi (Koch); length 0,3y $\mathrm{mm}$.

2. Specimens of the apple rust mite, Aculus schlechtendali (Nal.); length $0,07 \mathrm{~mm}$.

3. Tarnished plant bug, Lygus Zineolaris (P. de B.); length $5,6 \mathrm{~mm}$.

4. Apple redbug, Lygidea mendox Reut; length $6,6 \mathrm{~mm}$.

5. Green apple bug, Lygocoris communis (Knight); length 5,6 mm.

6. Apples attacked by the apple maggot, Rhagoletis pomonella (Walsh).

7. Male apple maggot; body length $5 \mathrm{~mm}$.

8. Adult plum curculio, Conotrachelus nenuphar (Hbst.); length $5 \mathrm{~mm}$.

9. Egg punctures of the plum curculio on newly set apples.

10. Feeding punctures of the plum curculio.

11. Caterplllar of the green frultworm, Orthosia hibisci (Guenée).

12. Adult green fruitworm; wingspan $40 \mathrm{~mm}$.

13. Scar on ripe apple caused by the caterpillar of the green frultworm.

Pho tos:

L.G. Simard, No. $1,2,3,4,6,7,8,10,11,13$

B. Drouln, No. 5,9 

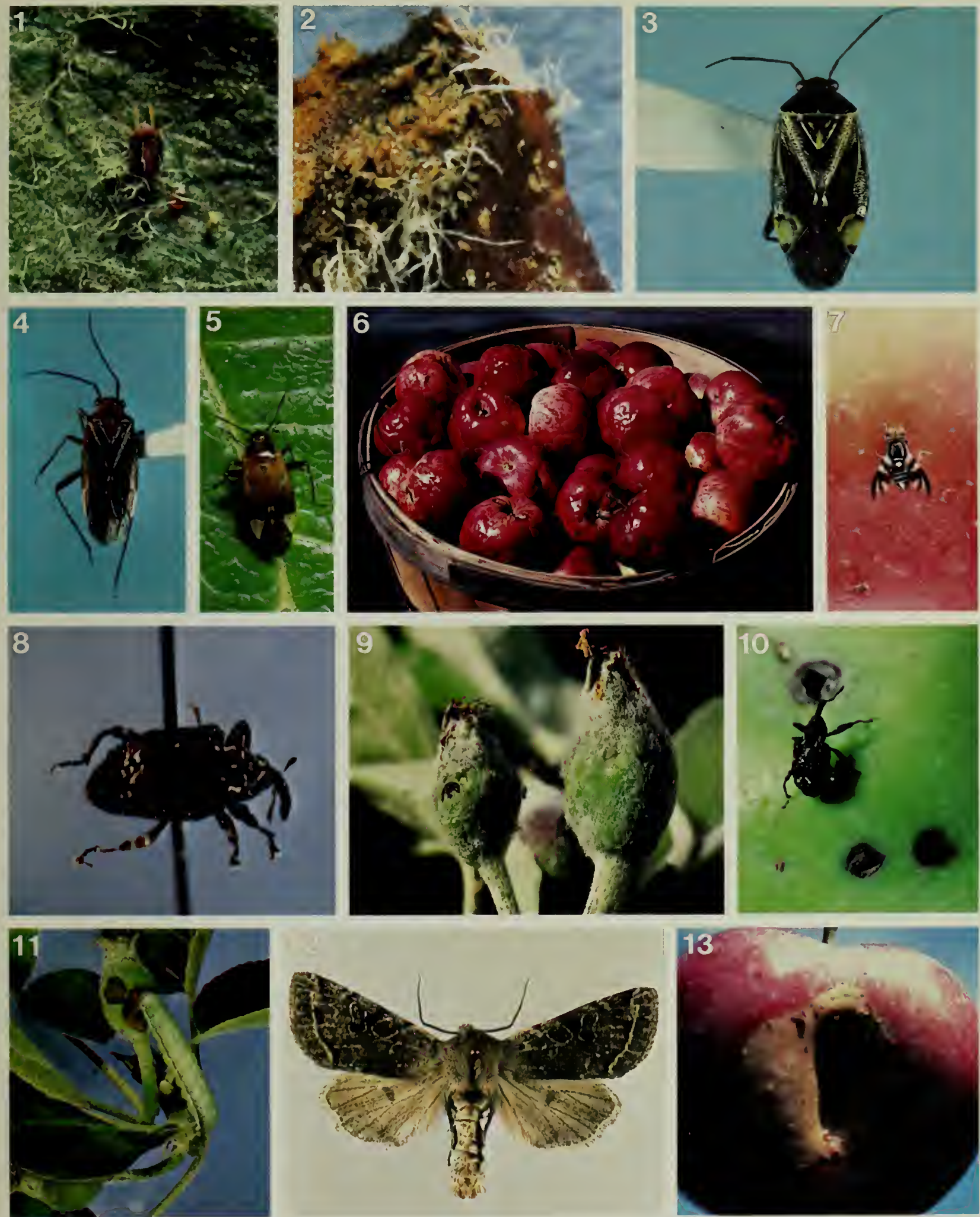
PLATE III - Secondary apple pests

1. Wingless forms of the apple aphid, Aphis pomi De G.

2. Wingless forms of the rosy apple aphid, Dysaphis plantaginea (Pass.).

3. Colonies of the rosy apple aphid on a leading shoot.

4. Adult oblique-banded leaf roller, Archips rosaceana (Harr.); length $11,5 \mathrm{~mm}$.

5. Apples attacked by the caterpillar of the oblique-banded leaf roller.

6. Adult codling moth, Laspeyresia pomonella (L.); lenght $10 \mathrm{~mm}$.

7. External appearance of a fruit containing the larva of the codling moth.

8. Adult and pupa of the eye-spotted bud moth, Spizonota ocellana (D. \& S.); length of adult $7,5 \mathrm{~mm}$.

9. Adult and nymphal cuticle of the frult-tree leaf roller, Archips argyrospizus (Wlk.); length of adult 10,6 mm.

10. Scars caused by caterpillars of the frult-tree leaf roller on mature apples.

11. Adult european apple sawfly, Hoplocompa testudinea (Klug); length $6 \mathrm{~mm}$.

Photos:

E. Drouln, No. $1,2,3,8,11$

L.G. Simard, No. $4,5,6,7,9,10$ 

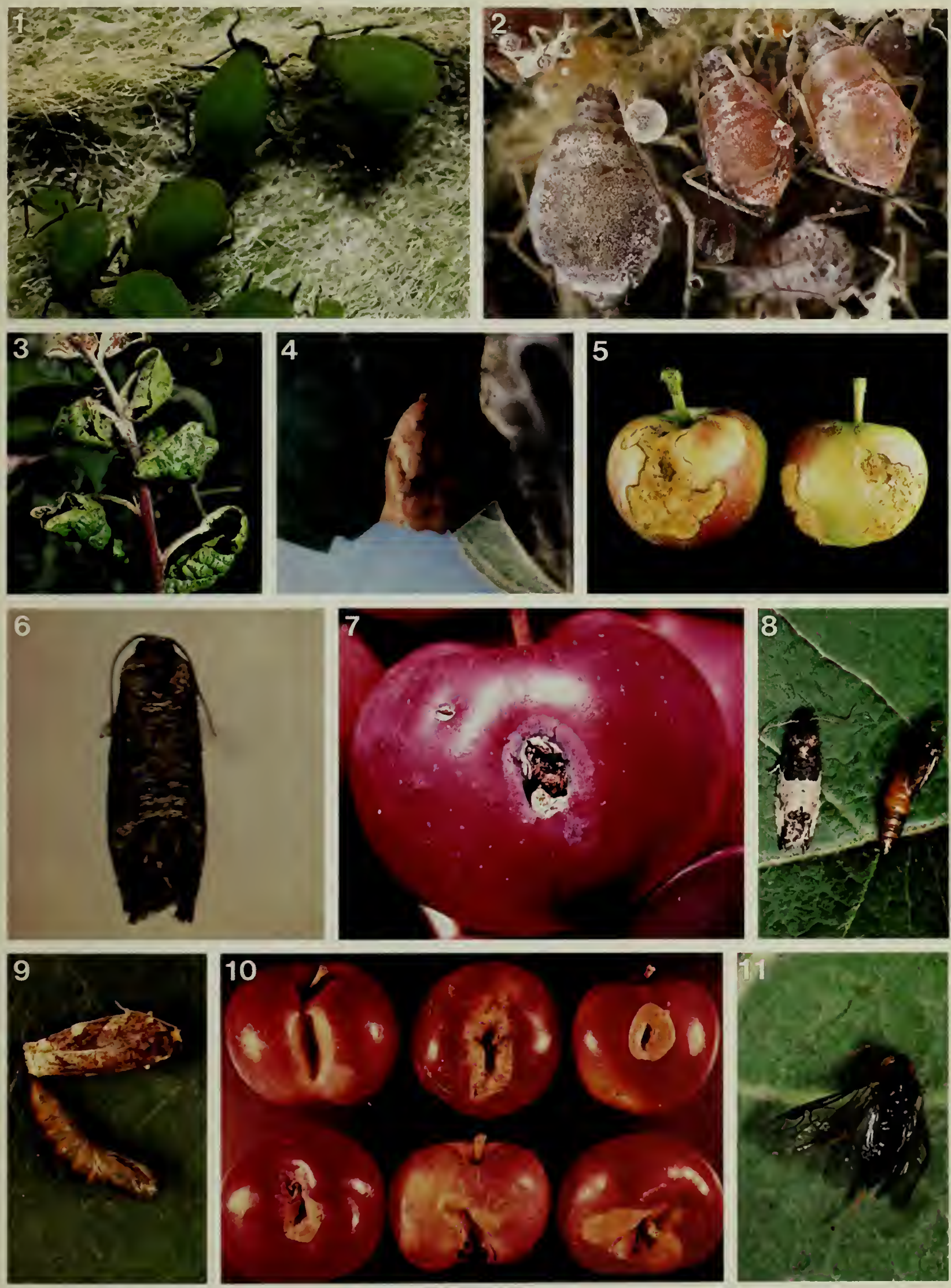

PLATE IV - Some natural enemies of apple pests

1. Alzothrombium Zerouxii Moss; length $3,3 \mathrm{~mm}$.

2. Syrphid egg; length $1 \mathrm{~mm}$.

3. Syrphid larva.

3a.Predatory ladybirds

4. Agathis Zaticinotus (Cresson); length 4,2 mm.

5. Diadegma obliteratus (Cresson); length 4,5 mm.

6. Macrocertrus iridescens French; length $3,2 \mathrm{~mm}$.

7. Aphidoletes aphidimyza (Rondan1); length $1,8 \mathrm{~mm}$.

8. Itoplectis conquisitor (Say); length $8,2 \mathrm{~mm}$.

9. Sarcophaga aldrichi (Park.); length 4,3 mm.

10. Apanteles ornigis (Weed); length 2,3 $\mathrm{mm}$.

11. Ascogaster quadridentatus Wes.; length $4,3 \mathrm{~mm}$.

12. A colony of Amblyseius fallacis (Garman); length of adult 0,32 mm.

Pho tos:

B. Drouln, No. 1

J. Touzin, No. 2, 3, 3a

L.G. Simard, No. $4,5,6,7,8,9,10,11,12$ 

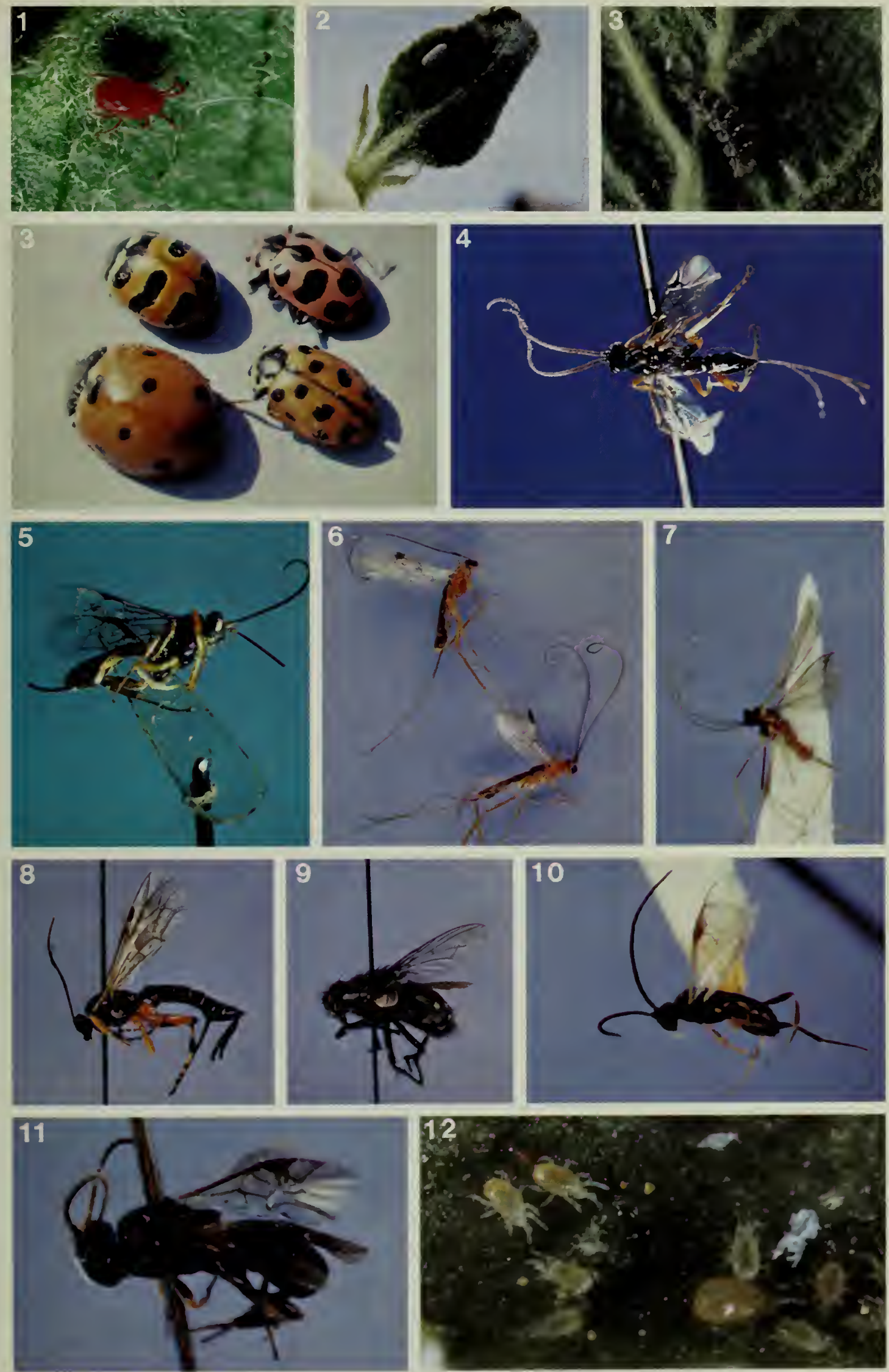

INDEX

Page

Page

Aculus schlechtendali see apple rust

mite.

Agathis Zaticinatus

.23, 25; P1.IV, fig.4 Azzothrombium Zerouxii...........

............. 4; P1.4, fig.1 Amblyseius falzacis..............

.........19, 22; P1.IV, fig.12

Anystis agizis............19, 22 Apanteles orginis.

........17, 18; P1.IV, fig.10 Aphidoletes aphidimyza........... ........19, 22, P1.IV, fig.6 Aphis pomi see apple aphid......... apple aphid.

...10, 23, 24, 28; P1.III, fig.1 apple grain aphid............5, 6 tentiform leafminer.......8, 9, 29 apple maggot...1, 16, 19, 20, 23, 27

28, 29, 30; P1.II, figs. 6 and 7 apple red bug.................

$\ldots \ldots 12,13,19,21$; P1.II, fig.4 apple rust mite...............

....5, 25, 26, 28; P1.II, fig.2 apple scab.................. apple seed chalcid.........17, 18 Archips argyrospilus see fruit-tree

leafroller. Archips rosaceana see oblique-

banded leafroller............. Argyrotaenia velutinana see red-

banded leafroller. Ascogaster quadridentatus.......... bait traps.................28, 29

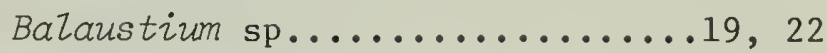
buffalo treehopper......19, 20, 25, 26 click beetles.................. 7 codling moth........16, 19, 20, 22, 25 $26,28,29,30 ;$ P1.III, figs. 6 and 7 Conotrachelus nenuphar see plum

curculio.

Ctenicera spp. see click beetles...... degree-days........2, 3, 5, 8, 10, 11 $12,13,14,15,16,17,19,23,25$ Diadegma obliteratus............... ..........23, 25; P1.IV, fig.5 dogwood borer............19, 21, 29 Dysaphis plantaginea see rosy apple aphid.

Eastern tent caterpillar $.5,7$ Eriosoma Zanigerum see woolly apple aphid...

European apple sawfly..

.......14, 28, 29; P1.III, fig.11 European fruit scale..........16, 17 European red mite.....1, 11, 14, 19, 20 $23,24,25,26,27,28$; P1.II, fig.1 eye-spotted bud moth.........5,6, 19 $21,23,24,25,27,28$;P1.III, fig. 8 forest tent caterpillar.........5, 7

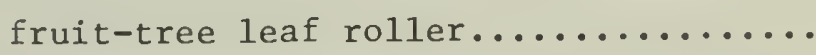
$\ldots \ldots \ldots \ldots \ldots 11,12,19,21,27$ 28, 29, 30; P1.III, figs. 9 and 10 fruit set...........17; P1.I, fig.9 ful1 bloom..........13; P1.I, fig.6 full pink...........12; P1.I, fig.6 Grapholita prunivora see lesser apple- 
green apple bug.

$\ldots \ldots 12,13,19,21$; P1.II, fig.5 green fruitworm........1, 3, 10, 27

28, 29; Pl.II, figs. 11, 12 and 13 green tip...........4; P1.I, fig.2 gypsy moth................, 9 half-inch green.......7; PI.I, fig. 3 Hop Zocampa testudinea see European

apple sawfly... Itoplectis conquisitor.

$.19,22 ; \mathrm{P} 1 . \mathrm{IV}, \mathrm{fig} .8$ lady beetles.....5, 7; P1.IV, fig.3a Laspeyresia pomonella see codling

moth.

Lepidosaphes $u$ Imi see oystershell

scale.

lesser appleworm.

$\ldots \ldots 14,15,19,20,25,26,27,29$ Lithocolletis blancardella see

tentiform leafminer............ Lithocolzetis cartaegelza.........9 Lithocolletis malimalifoliella.....99 Lithocolzetis scuderelza.........99 Lygidea mendax see apple red bug. Lygocoris communis see green apple

bug...

Lygus lineolaris see tarnished plant

bug.

Lymantria dispar see gypsy moth...... Macrocentrus iridescens.

..........19, 22; P1.IV, fig.6 Macrodactylus subspinosus see rose chafer. MaZacosoma americanum see Eastern

tent caterpillar... Malacosoma disstria see forest tent oblique-banded leafroller............ .............. $6,19,20,22$ $27,28,29,30$; P1.III, figs. 4 and 5 Orthosia hibisci see green fruitworm... oystershell scale............16, 17 pale apple leafroller............ 4 Panonychus uImi see European red mite.. pear thrips...............12, 13 pests, major....1, 2, 3, 10, 11, 14, 17 $19,23,25,27,28 ;$ P1.II, figs.1-13 pests, occasional.

$. .2,3,5,8,12,14,17,19,27,28$ pests, secondary. $2,5,8,10,11,12,16$ $19,23,25,27,28$; P1.III,figs.1-11 petal fall...........15; PI.I, fig. 8 pheromone traps.............28, 29 pink bud.............10; P1.I, fig. 5 plant bugs................. 27, 28 plum curculio.....1,11, 14, 17, 18, 23 24, 27, 28; P1.II, figs. 8, 9 and 10 Polynema striaticome..........19, 22 Pseudexentera mali see pale apple leafroller. Quadraspidiotus ostreaeformis see

European fruit scale. red-banded leafroller.

$\ldots \ldots \ldots 5,6,25,26,27,28,29,30$ rose chafer................19, 21 Rhagoletis pomonezla see apple maggot.. Rhopalosiphum fitchii see apple grain aphid... rosy apple aphid.

.......8, 9; P1.III, figs. 2 and 3 Sarcophaga aldnihi.23, 25; P1.IV, fig.9 Spizonota ocelzana see eye-spotted bud moth. spring dormancy........3; P1.I, fig.1 


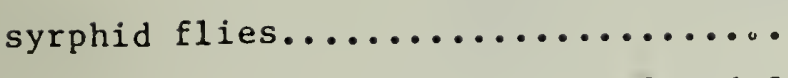

.......5, 7, P1.IV, figs.2 and 3 Taeniothrips inconsequens see pear thrips.

tarnished plant bug.

$3,5,19,27,28,29 ; \mathrm{P} 1 . \mathrm{II}, \mathrm{fig} .3$ Tetranychus urticae see two-spotted spider mite..................
Thamosphecia scitula see dogwood borer.

tight cluster.........9; P1.I, fig. 4 Torymus varians see apple seed chalcid.

Trichogramma minutum.........23, 24 two-spotted spider mite.......... Venturia inaequalis see apple scab... woolly apple aphid.....20, 21, 27, 28 


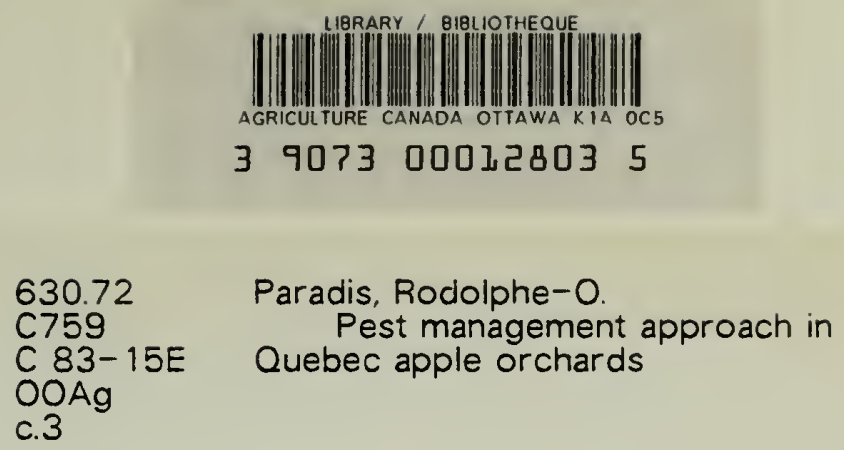
